\title{
Effect of Intercroping Maize-Soybean on Grain Quality Traits in Kenya
}

\author{
Habineza M. Jean Pierre ${ }^{1,2}$, Josiah M. Kinama ${ }^{2}$, Florence M. Olubayo ${ }^{2}$, Susan W. Wanderi ${ }^{3}$, \\ James W. Muthomi ${ }^{2} \&$ Felister M. Nzuve ${ }^{2}$ \\ ${ }^{1}$ University of Goma (UNIGOM), Goma, Democratic Republic of Congo \\ ${ }^{2}$ Department of Plant Science and Crop Protection, University of Nairobi, Nairobi, Kenya \\ ${ }^{3}$ Kenya Agricultural and Livestock Research Organisation (KARLO), Kenya \\ Correspondence: Habineza M. Jean Pierre, University of Goma (UNIGOM), Goma, Democratic Republic of \\ Congo. Tel: 243-895-271-821. E-mail: ir.jphaby@gmail.com
}

Received: September 13, 2017

Accepted: December 14, 2017 Online Published: January 15, 2018

doi:10.5539/jas.v10n2p341

URL: https://doi.org/10.5539/jas.v10n2p341

\begin{abstract}
An experiment was conducted in Kenya to determine the effect of intercropping maize-soybean on soybean grain quality traits. A randomized complete block design replicated three times with seven treatments was used. Data were collected and analysed for soybean protein content, oil content and dry matter while grain size was done for maize and soybean. Data were subjected to ANOVA and means separated using $\operatorname{LSD}_{0.05}$. The results showed that TGX1990-5F variety recorded high protein content $(p \leq 0.05)$ in sole crop compared to intercropping with $42.96 \%$ and $38.4 \%$ respectively while SB19 obtained $36.57 \%$ and $40.41 \%$ of protein between sites for the first season. A bout the second season, TGX1990-5F gave $40.84 \%$ of protein compared to $31.98 \%$ for GAZELLE in intercrop at both sites. GAZELLE showed higher oil content followed by TGX1990-5F and SB19 was the last in both seasons. TGX1990-5F showed higher dry matter followed by GAZELLE and SB19 was the last in intercrop. In addition, GAZELLE a local variety showed greater size than SB19 in both rainy seasons. Intercropping affected slightly the protein content, oil content and gain size than sole crop but it did not affect the dry matter in both seasons.Thus, TGX1990-5F can be recommended to small-scale farmers for intercropping with maize because it produced higher value of protein and small-scale farmers could use it to fight mal nutrition. GAZELLE variety can be also recommended for oil production. Maize grain size was not affected by intercropping system.
\end{abstract}

Keywords: grain size, intercropping system, maize-soybean, oil content, protein content

\section{Introduction}

Soybeans (Glycine max) serve as one of the most impotant crops in the world, not only as an oil seed crop and feed for livestock and aquaculture, but also as a good source of protein for the human diet and as a biofuel feestock (Masuda \& Goldsmith, 2009). The world soybean production increased by 4.6\% annually from 1961 to 2007 and reached average annual production of 217.6million tons in 2005-2007 (Masuda \& Goldsmith, 2014). Weinhold and Killick (2011) reported that, the increase of soy production both reduces poverty indicators and raises median rural incomes. Soybean cultivation is highly concentrated geographically, with only four countries-USA, Brazil, Argentine and China - accounting for almost $90 \%$ of wold output. Asia — excluding China - and Africa, the two regions where most of the food insecure countries are located, together account for only $5 \%$ of production. Among countries classified as undernourished, only India and Bolivia are significant producers of soybeans (Thoenes, 2015). In addition, Bill and Melinda (2011) reported that, for the African coutries, the leading production is South Africa (588 k MT), Zambia (112 k MT), Zimbabwe (50 k MT), Malawi (73 k MT), Mozambique (18 k MT), Angola (15 k MT) and DRC ( $5 \mathrm{k}$ MT). The remarkable success of the soybean in temperate zones is well known, but there is also a good potential role for the crop in many cropping systems of the tropics and subtropics, where farms tend to be smaller and less mechanized (Thoenes, 2015). Among those tropics countries Kenya is included but its pourcentage soybean production is quite low and is not quoted above as soybean producer counrty. The cropping system which could help small scale famers to raise their production could be the intercropping. However, Protein content, oil content and grain size can be affected positively or negatively by growth conditions of crops (Lithourgidis et al., 2011). Intercropping, the agricultural practice of cultivating two or more crops in the same space at the same time, is an old and commonly cropping system used which targets to match efficiently crop 
demands to the available growth resources and labor (Lithourgidis et al., 2011). The stability under intercropping can be attributed to the partial restoration of diversity that is missed under sole crops. According to this statement of view, intercropping allows high insurance against crop failure, notably in environments known for heavy weather conditions like frost, flood, drought, and overall provides hight financial stability for farmers (Lithourgidis et al., 2011). Moreover, legumes enrich soil by fixing the atmospheric nitrogen transforming it and other mineral from an inorganic form to forms that are avaible for uptake by crops ( $\mathrm{Li}$ et al., 2012). However, more interaction mechanisms that happen between plant species when intercropped as well as the effect of intercrop on the following crop in the fallow might have effects on grain quality. This has been shown determining the effect of intercropping on a series of quality factors, such as physical grain quality, ratio of nitrogen and sulphur concentrations, protein quality for wheat and fababean (Erik, 2005). Musa et al. (2011) reported that intercropping increased chemical composition as dry matter, ash, protein, fibber content and tannin content of cowpea in maize-cowpea intercropping. Eskandari and Ghanbari (2009), Yucel and Avci (2009) showed that, intercropping legume-cereal increased crude protein than monocrop, while Jayanta et al. (2015) found that, intercropping maize-soybean increased protein and nitrogen content in both grains, nitrogen content in stover and total nitrogen uptake with $75-100 \%$ of recommended nitrogen. Moreover, Abdel et al. (2016) revealed that intercropping soybean-sunflower spaced at $20 \mathrm{~cm}$ (soybean) had the highest grain oil yields per ha compared to other spacing. In addition, intercropping maize-soybean affected negatively the value of soybean protein and oil content where in pure crops soybean showed $38.47 \%$ compared to $36.76 \%$ in intercrop for protein and $19.15 \%$ compared to $17.97 \%$ for oil content respectively in sole crop compared to the intercrop (Mirela \& Roman, 2013). Dragicevic et al. (2017) reported that, some chemicals content (antioxidant) were enhanced mostly by alternating strips in maize grain and by alternating rows in soybean grain, in maize-soybean intercropping system. Furthermore, intercropping maize-soybean with increasing $\mathrm{N}$ application can improve grain of maize and soybean physiological characters, but their effects will be decreased with increasing $\mathrm{N}$ fertilisation rate (Zhang et al., 2014). However, intercropping of pea-barley like a way of improving complementary $\mathrm{N}$, increases the protein production and reduces weed problem in intercropping systems without herbicide use (Hauggaard et al., 2001). Laurent et al. (2014) reported that, intercropping seems to be a important agronomic solution for organic arable cropping, especialy in low-N input systems, by improving yields of environmental competition for resource use, cereal grain protein concentration due to non proportional competition for soil mineral $\mathrm{N}$ and other plant growth factors, weed control, compared to sole crops. Nevertheless, analysis of grain quality in cereals-legumes cropping system showed that, crude protein concentration of intercropped cereals increased compared to sole crops in all experimental sites. Pea increased the concetration of crude protein in intercrops yield compared with sole cereals in the Dotnura site (Kadziuliene et al., 2009). Moreover, Staniak et al. (2014) found that, intercropping of cereals-legumes enhances protein content in the grain cereals, increasing also the yield of crude protein in the biomass of the component crops. Šarūnaite et al. (2010) said that,the increases of crude protein was higher in wheat grain yield when wheat had been grown in intercrop with bean. In addition, intercropping had no significant effect on grain oil content of castor. It was concluded that, castor, could be intercropped efficientely with beans without affecting food crop production and the resultant grain oil content of castor. Hence the need in this study to assess the effect of intercropping maize- soybean on protein, oil content and grain size at Embu and Mwea sites in Kenya.

\section{Materials and Methods}

The experiments were carried out in two sites during two rain seasons of (2016 and 2017). The first site was KALRO-Embu, located in Embu County in the Eastern part of Kenya and lying between latitudes $0^{\circ} 08^{\prime} 35^{\prime \prime} \mathrm{S}$ and a longitude $37^{\circ} 27^{\prime} 02^{\prime \prime}$ E. KALRO-Mwea is in Kirinyaga county, situated in the Central Region of Kenya at a latitude of $00^{\circ} 37^{\prime} \mathrm{S}$ and a longitude of $37^{\circ} 20^{\prime} \mathrm{E}$ (Kirinyaga county, 2014 and Embu county, 2014). Land preparation was done by ploughing using ox-drawn equipment. The varieties of soybean used were: SB19, GAZELLE, TGX1990-5F and one variety of maize (Duma 43) for intercropping with soybean. The experiment was laid out in a randomized complete block design (RCBD) replicated three times with seven treatments including: $\mathrm{T}_{1}$ : SB19 (Hybrid), $\mathrm{T}_{2}$ : GAZELLE (Local), $\mathrm{T}_{3}$ : TGX1990-5F (Hybrid), $\mathrm{T}_{4}$ : SB19+MAIZE, $\mathrm{T}_{5}$ : GAZELLE+MAIZE, $\mathrm{T}_{6}$ : TGX1990-5F+MAIZE, $\mathrm{T}_{7}$ : MAIZE (DUMA 43). The spacing used and densities were: Monocrop soybean: 166,666.66 plants ha ${ }^{-1}(40 \mathrm{~cm} \times 15 \mathrm{~cm})$, Soybean intercropped with maize: 83,333.33 plants $\mathrm{ha}^{-1}(80 \mathrm{~cm} \times 15 \mathrm{~cm})$, Monocrop maize: 50,000 plants ha $^{-1}(80 \mathrm{~cm} \times 25 \mathrm{~cm})$, Maize intercropped with soybean: 50,000 plants ha ${ }^{-1}(80 \mathrm{~cm} \times 25 \mathrm{~cm})$. The total area of the experiment was $420 \mathrm{~m}^{2}$. In total, the experiment had 2700 plants of soybean in which 900 plants were in intercrop with maize and 1800 plants were in sole crops. The total density in whole experiment for maize was 720 plants in sole crops as in intercrop. The arrangement of intercropping was 1:1 with, one row of maize intercepted by one row of soybean. The experiments received a basal application of $10.5 \mathrm{~kg}$ of DAP per site at the rate of $250 \mathrm{~kg} \mathrm{ha}^{-1}$, meaning that each plot received $300 \mathrm{~g}$ of 
fertilizer and the application was done by row (Roy et al., 2006). The dosage of fertilizer used per plant for maize in sole crop was $5 \mathrm{~g}, 1.5 \mathrm{~g}$ for soybean in sole crop and $1.875 \mathrm{~g}$ per plant in maize-soybean intercropped. The first season was planted on $9^{\text {th }}$ Jun 2016 at Embu and on $10^{\text {th }}$ at Mwea. The first weeding was done on $24^{\text {th }}$ Jun 2016 in both sites. Harvesting was done on $8^{\text {th }}$ October 2016 at Mwea and on 21 October 2016 at Embu respectively. The second season was planted on $8^{\text {th }}$ November 2016 and the first weeding was done on $28^{\text {th }}$ November 2016. The harvesting was done on $12^{\text {th }}$ at Mwea, while it happened on $25^{\text {th }}$ at Embu. The dosage of fertilizer which was applied in the first season was the same as the second season. Because of insufficient rain fall, the trials received supplement by irrigation but the situation of rain fall was drastic and so bad in the second season. The plants from the middle of the plot were taken in both sites and seasons to determine maize-soybean grain quality. Data were taken on maize grain size, soybean grain size, soybean protein content, soybean oil content and soybean dry matter.

\subsection{Intercropping on Grain Quality Traits}

\subsubsection{Soybean and Maize Grain Size Analysis}

The grain size was measured by a stack of sieves with hole-diameter ranging from $(5.5 \mathrm{~mm}$ to $10 \mathrm{~mm})$ for maize and $(4 \mathrm{~mm}$ to $8 \mathrm{~mm})$ for soybean and seven size bins were generated from 100 grains taken as sample for maize and soybean each and grain size were assessed in \%. The operation was done in the lab of department of Food Science (CAVS) (Shahin \& Symons, 2005).

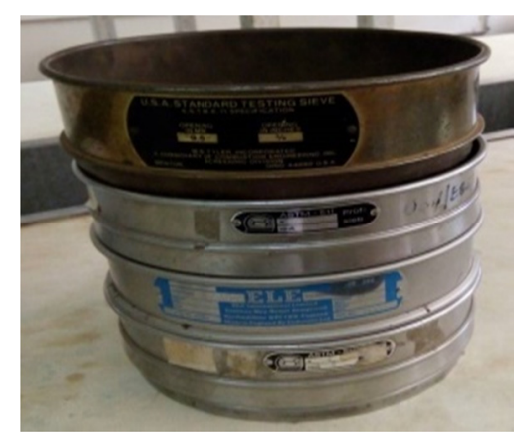

Figure 1. Sieves used for grain size generation

\subsubsection{Crude Protein Determination}

The crude protein has been determined by the kjedhal method as described by (Katerine, 2012),

$$
\% \text { Protein }=\frac{14 \times 6.25 \times 100 \times 0.1(\mathrm{NaoH})}{\text { weight } \times 1000} \times \text { Titre }
$$

Where, $14=$ Molecule weight of nitrogen, $625=$ Convention factor to protein, $0.1=$ Normality for $\mathrm{NaOH}$, Blank titre: Sample titre.
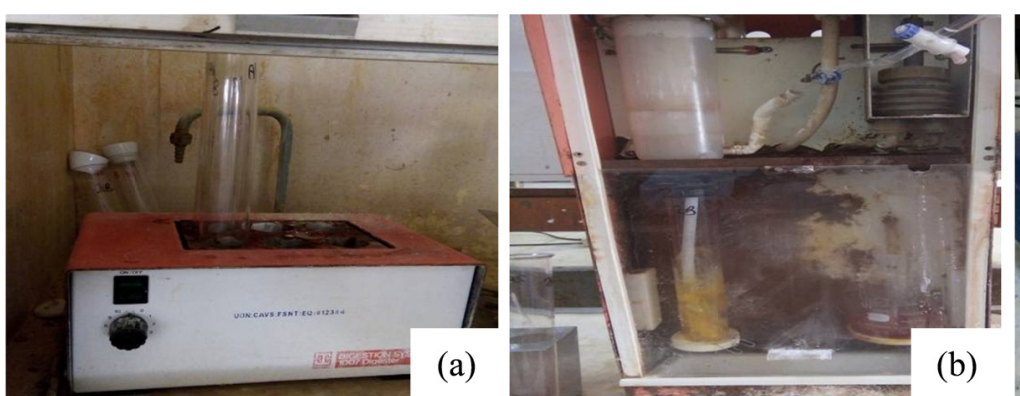

(b)

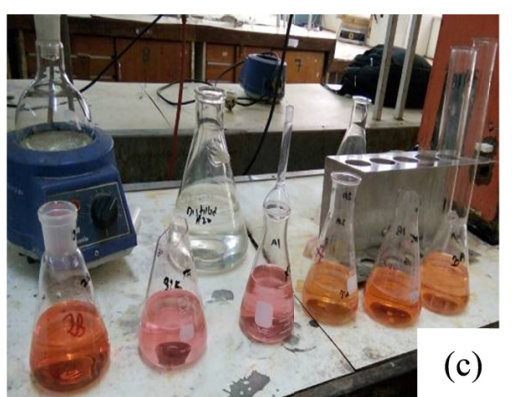

(c)

Figure 2. (a) Digestion of protein in the digester, (b) Distillation of protein, (c) Protein after distillation and titration 


\subsubsection{Crude Oil Determination}

The crude oil has been determined using the sohlet method as described by (CSIRO and the victorian goverment, 2006).

$$
\% \text { Fat determination }=\frac{\text { Flask }+ \text { Oil }}{\text { Sample weight }} \times 100
$$
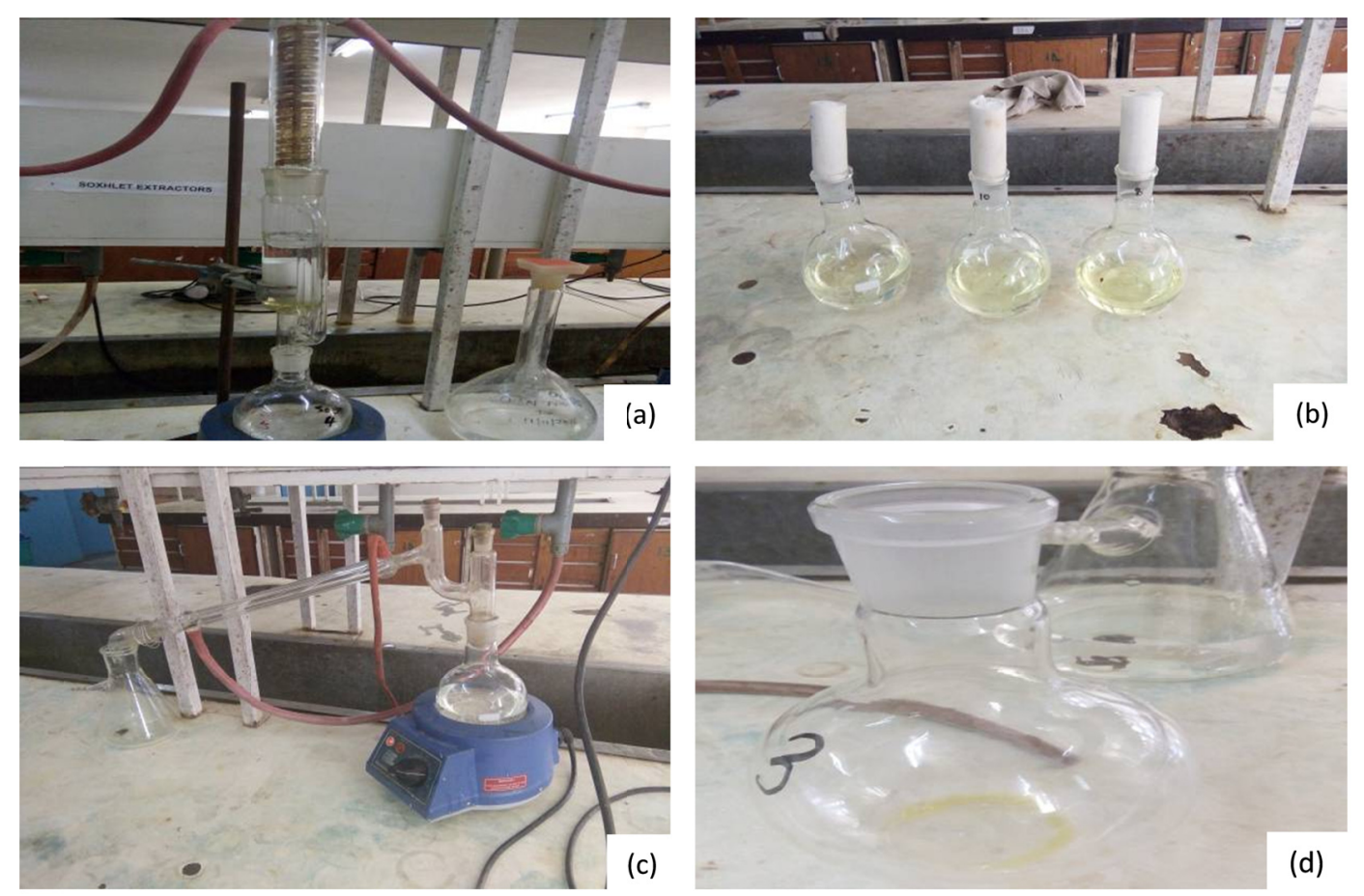

Figure 3. (a) Extraction of the soybean oil with soxhelt method, (b) Soybean oil after extraction, (c) Separation of petrolium with soybean oil with evaporation, (d) Soybean oil after evaporation

\subsubsection{Soybean Dry Matter Analysis}

The moisture was evaporated from the soybean sample in an air oven tool at $103{ }^{\circ} \mathrm{C}$. Dry matter was calculated as residue remaining during 3 hours.

$$
\text { Total DM }=\frac{\mathrm{W} 6-\mathrm{W} 4}{\mathrm{~W} 5-\mathrm{W} 4} \times 100
$$

Where, DM = Dry Matter, W4 = Tare weight of dish in grams, W5 = Initial weight of sample and dish in grams, W6 $=$ Dry weight of sample and dish in grams; $\%$ Total Moisture $=100-\%$ DM (PFI, 1978). The data were analyzed by Gen stat program fourth edition, 2013 and the least significant difference (LSD) was used to differentiate the means on threshold of $(p \leq 0.05)$. The table of analysis of variance (ANOVA) was important to know the source of variance (ILRI-ICRAF, 2007).

\section{Results}

\subsection{Weather Data during the Experiment Duration Long Rain 2016}

The mean rain falls $(\mathrm{mm})$ during the experiment duration were $3.21 \mathrm{~mm}$ and $0.007 \mathrm{~mm}$ at Embu and Mwea respectively. Rain fall from Mwea were very negligible. However, the mean for temperature and relative humidity were respectively $21.42{ }^{\circ} \mathrm{C}$ and $63.54 \%$ at Mwea (Figure 4). 

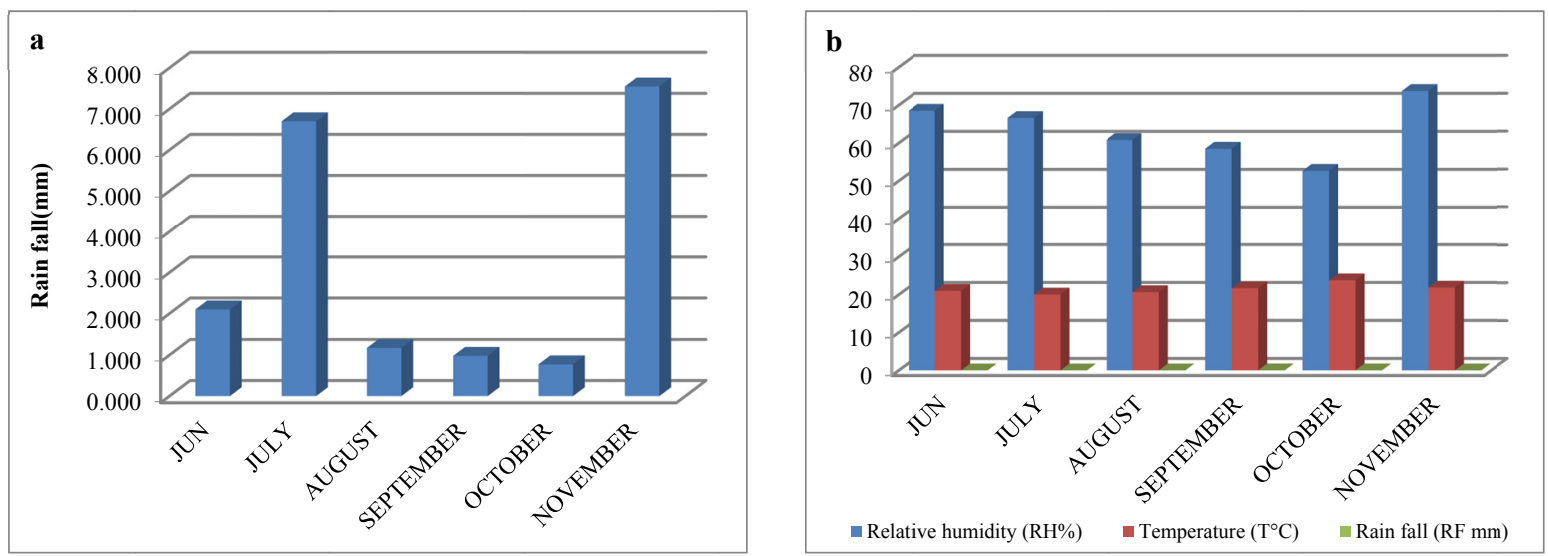

Figure 4. (a) Weather data at EMBU site, (b) Weather data at MWEA site

\subsection{Intercropping on Grain Quality Traits}

\subsubsection{Effect of Intercropping on Soybean and Maize Grain Size}

Soybean grains with $6 \mathrm{~mm}$ showed significant difference between sites and seasons $(\mathrm{p} \leq 0.05)$. The variety for SB19 recorded the higher value of $35.3 \%$ more than $23.3 \%$ for GAZELLE and TGX1990-5 recorded the lowest value of $2.7 \%$ in sole crop. TGX1990-5F variety showed higher value of $58 \%$ followed by SB19 $(35.7 \%)$ and the last was GAZELLE with $6.3 \%$ in intercrop in the first season. The percentage obtained in short rain was the same in the first season (Figures 6 and 8). Soyean grain size with $7 \mathrm{~mm}$ showed significant difference between sites and seasons $(\mathrm{p} \leq 0.05)$. GAZELLE showed $16 \%$ more than $6.7 \%$ for TGX1990-5F and the last was SB19 with $1.7 \%$ in sole crop at Embu. GAZELLE presented $35.7 \%$ more than $10.7 \%$ for TGX1990-5F and SB19 showed the lowest value of $0.3 \%$ in intercrop at Embu. The variety GAZELLE showed $32 \%$ bigger than $8.3 \%$ for SB19 and TGX1990-5F showed the lowest value of 6\% in sole crop at Mwea. GAZELLE presented 23\% bigger than $8.7 \%$ for TGX1990-5F and SB19 showed the lowest value of $0.7 \%$ in intercrop at Mwea. However, soybean with $4 \mathrm{~mm}, 5.6 \mathrm{~mm}, 6.5 \mathrm{~mm}$ and $8 \mathrm{~mm}$ did not give significant difference $(\mathrm{p} \leq 0.05)$. Intercropping affected negatively the soybean grain size according to the results found in both rainy seasons and sites. However, Mwea site produced better grain in size compared to Embu. GAZELLE gave big grain size of $(7 \mathrm{~mm})$ compared to other varieties. The variety which had smallest grain size $(6 \mathrm{~mm})$ was SB19 where the higher value of grain size was $96 \%$ at Mwea in intercropping compared to GAZELLE with 1\% in intercropping too (Figures 6 and 8).
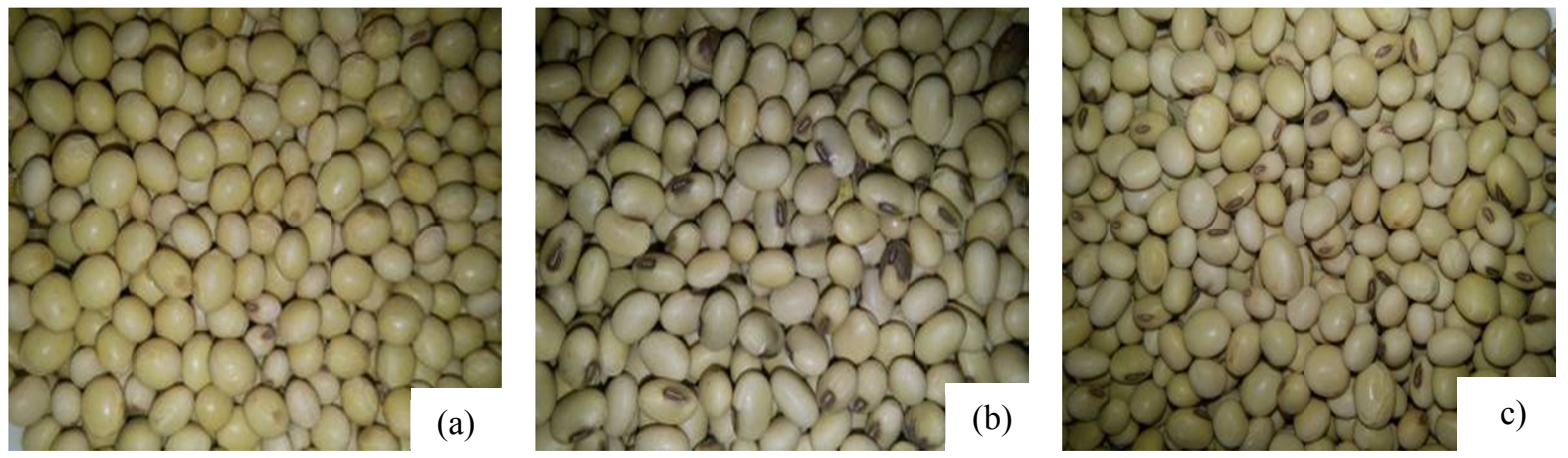

Figure 5. Grain of soybean varieties after harvesting; (a) GAZELLE, (b) TGX1990-5F, (c) SB19

Grain size for maize in intercropping and in sole crop did not give significant difference between sites and seasons $(\mathrm{p} \leq 0.05)$. Nevertheless, the biggest percentage of grain size was found at Embu site compared to Mwea $(9.5 \mathrm{~mm})$ against $(7 \mathrm{~mm}$ ) respectively (Figures 7 and 9). So, Embu produced better maize grains than Mwea in both rains seasons. Intercropping did not affect negatively the maize grain size at both sites and both rains seasons. Maize 
grain size was not generated for the long rain 2016 at Mwea because plants were attacked by MLN and they didn't produce grains but they produced biomass (Figure 7).

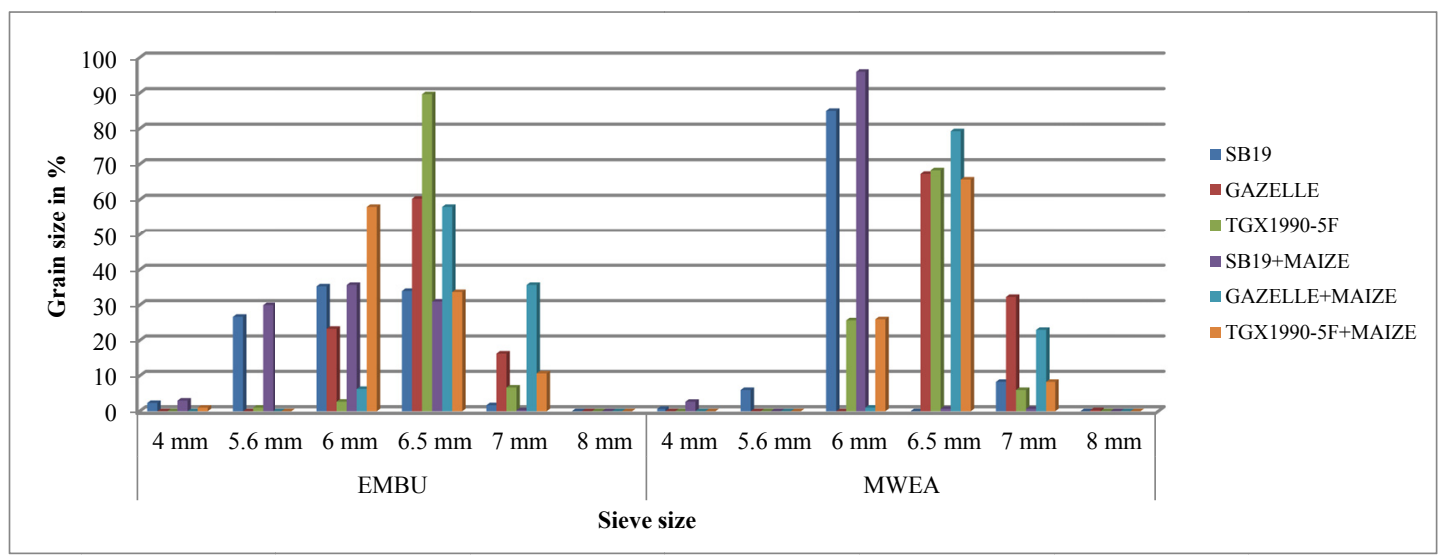

Figue 6. Mean of grain size of different varieties of soybean in sole crop and in intercropping in $\%$ (Long rain 2016)

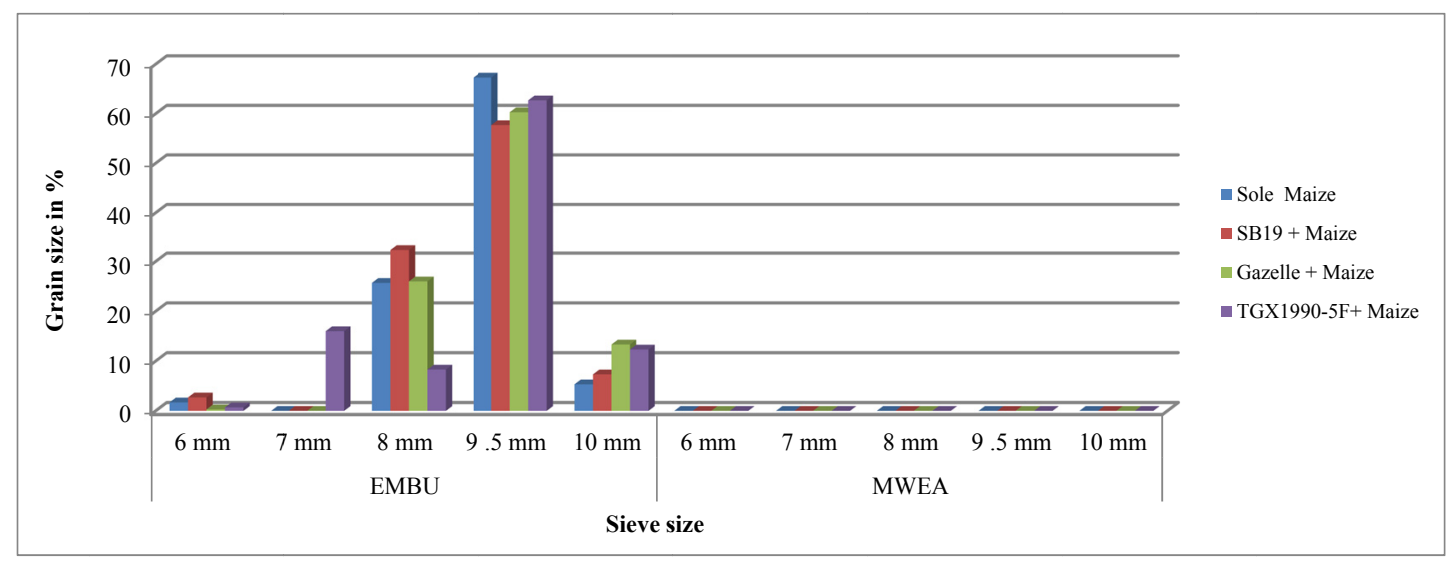

Figue 7. Mean of grain size for Maize (Duma 43) in sole crop and in intercropping in\%

(Long rain 2016)

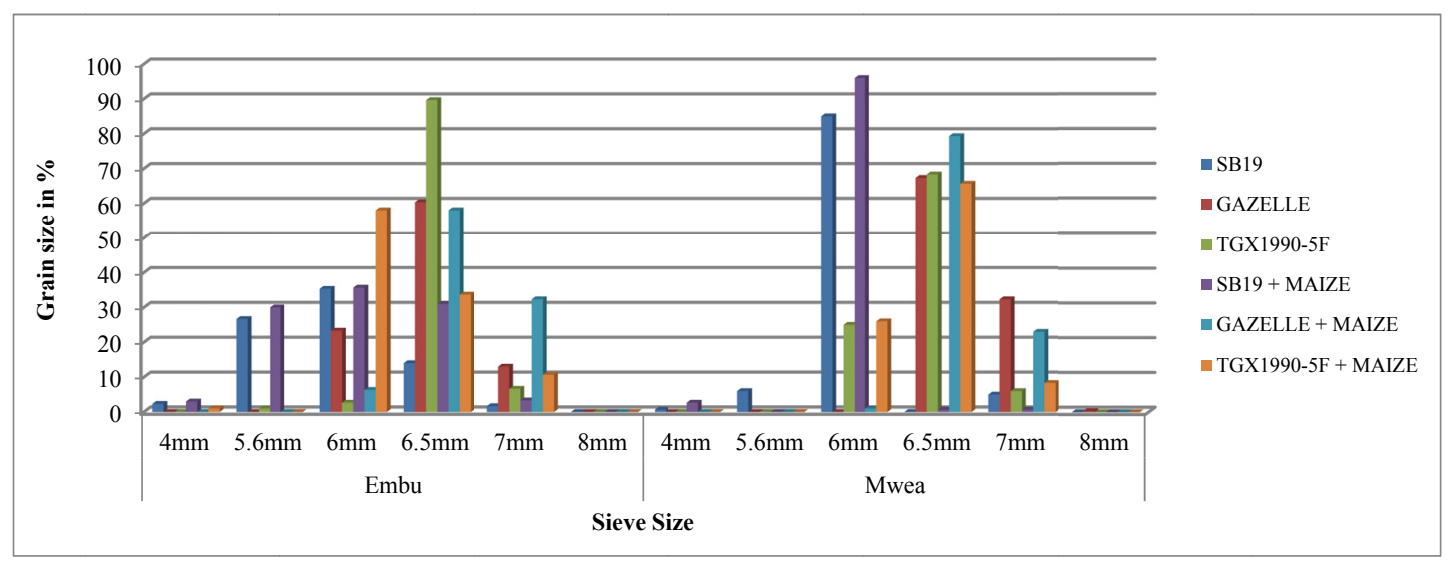

Figue 8. Mean of grain size of different varieties of soybean in sole crop and in intercropping in $\%$ (short rains 2016-2017) 


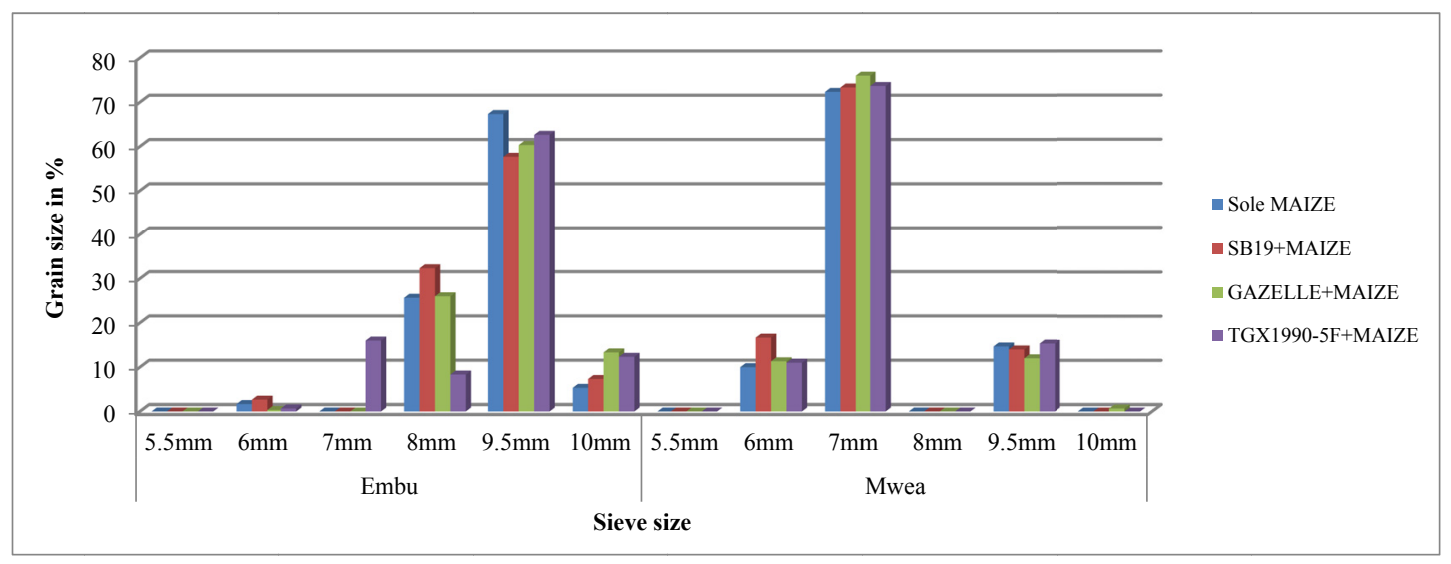

Figue 9. Mean of grain size for Maize (Duma 43) in sole crop and in intercropping in\% (short rains 2016-2017)

\subsubsection{Effect of Intercropping on Protein, Oil Content and Dry Matter}

Soybean protein did not show significant difference between sites for the long rains 2016, but differents treatments gave significant difference $(\mathrm{p} \leq 0.05)$. Soybean protein content was slighly higher in the long rain season (39.34\%) compared to the short rain season (35.85\%). Protein content ranged from $36 \%$ to $43 \%$ at Mwea while it ranged from $36 \%$ to $42 \%$ at Embu for the long rain season. However, during the short rains, it ranged from $31 \%$ to $40 \%$ at Mwea while it ranged from $36 \%$ to $41 \%$ at Embu. It means that during the long rains soybean from Mwea increased slightly the value of protein content than soybean from Embu while it was the contrary in the short rains. TGX1990-5F showed higher value of $42.89 \%$ of protein followed by GAZELLE (39.18\%) in sole crop compared to SB19 with $36.64 \%$ of protein content. However, SB19 produced more protein content (40.43\%) followed by TGX1990-5F (38.43\%) compared to GAZELLE with 37.99\% at Embu. From Mwea site, TGX1990-5F showed higher protein content of $43.02 \%$ than GAZELLE with $39.36 \%$ in sole crop compared to SB19 with $36.64 \%$. Intercropping reduced soybean protein content considering the higher value of protein content for each variety produced in sole crop than in intercropping i.e. GAZELLE showed the highest protein content for $40.39 \%$ than TGX1990-5F and SB19 which gave similar value of protein content of $38 \%$. Depending to the short rains, protein content gave significant diference between sites $(\mathrm{p} \leq 0.05)$, i.e., TGX1990-5F protein content was $40.14 \%$ more than $36.15 \%$ compared to $34.53 \%$ mean for SB19 in intercrop. The same situation happened at Mwea site, where TGX1990-5F was first in intercropping followed by SB19 compared to GAZELLE. TGX1990-5F is considered as a variety with high value of protein content because for the long rains and the short rains, it showed high protein values in sole crop and in intercrop (Table 1). However, oil content for the long rains of 2016 gave significant difference between sites and seasons, and GAZELLE gave high values of $21.08 \%$ in sole crop followed by TGX1990-5F with $18.63 \%$ compared to SB19 with $16.46 \%$ at Embu.Variety GAZELLE recorded higher value of oil content of $16.68 \%$ than TGX1990-5F with $12.77 \%$ compared to SB19 with lower value of $9.37 \%$ in intercrop. GAZELLE variety had higher values of oil content at Mwea with $22.98 \%$ than SB19 with $15.29 \%$ compared to TGX1990-5F in sole crop with $12.78 \%$. GAZELLE variety gave high value of oil content followed by SB19 and TGX1990-5F showed the lowest oil content in intercrop. During the short rain, variety SB19 had lowest value of oil content and TGX1990-5F was in the middle while GAZELLE ranked the first. However, intercropping reduced the value of oil content for both sites and both rainy seasons (Table 1). Dry matter gave significant difference between sites and seasons $(\mathrm{p} \leq 0.05)$. Embu site did not give significant difference for both rainy seasons. Dry matter ranged from $14 \%$ to $16 \%$ for the first season while it ranged from $15 \%$ to $16 \%$ in the short rains in sole crop and in intercrop. The significant difference was shown at Mwea both rains seasons, and TGX1990-5F had higher value of dry matter of $18.82 \%$ than SB19 with $16.77 \%$ compared to $15.74 \%$ for GAZELLE sole crop. TGX1990-5F variety showed the same results in intercrop compared to GAZELLE and SB19 which had the same value of dry matter of $15 \%$. For the short rains, TGX1990-5F presented good perfomance giving higher dry matter of $17.19 \%$ than $16.77 \%$ for SB19 compared to GAZELLE with $15.74 \%$ in sole crop. TGX1990-5F showed bigger dry matter of $18.82 \%$ followed by GAZELLE with $18.19 \%$ and SB19 gave the lowest value of $15.11 \%$ in intercrop. Thus during the long rains and short rain season TGX1990-5F gave higher values of dry matter than other varieties in intercropping and in sole crop. However, intercropping did not affect negatively the value of dry matter in percentage (Table 1). 
Table 1. Soybean protein content, oil content and dry matter at Embu and Mwea 2016-2017

\begin{tabular}{|c|c|c|c|c|c|c|c|c|c|}
\hline \multicolumn{10}{|c|}{ Long rains 2016} \\
\hline \multirow{2}{*}{ Treatment } & \multicolumn{3}{|c|}{$\%$ Protein content } & \multicolumn{3}{|c|}{$\%$ Oil content } & \multicolumn{3}{|c|}{$\%$ Dry matter } \\
\hline & Embu & Mwea & Mean & Embu & Mwea & Mean & Embu & Mwea & Mean \\
\hline SB19 & $36.51 \mathrm{~d}$ & $36.64 \mathrm{c}$ & $36.57 \mathrm{a}$ & $16.46 \mathrm{c}$ & $15.29 \mathrm{~d}$ & $15.88 \mathrm{~d}$ & $16.68 \mathrm{a}$ & $16.77 \mathrm{ab}$ & $16.73 \mathrm{ab}$ \\
\hline GAZELLE & $39.18 b c$ & $39.36 b$ & $39.27 \mathrm{a}$ & $21.08 \mathrm{a}$ & $22.98 \mathrm{a}$ & $22.03 \mathrm{a}$ & $15.82 \mathrm{a}$ & $15.74 \mathrm{ab}$ & $15.78 \mathrm{ab}$ \\
\hline TGX1990-5F & $42.89 \mathrm{a}$ & $43.02 \mathrm{a}$ & $42.96 \mathrm{a}$ & $18.63 \mathrm{~b}$ & $12.78 \mathrm{e}$ & $15.71 d$ & $16.84 \mathrm{a}$ & $18.21 \mathrm{ab}$ & $17.53 \mathrm{a}$ \\
\hline SB19+MAIZE & $40.43 b$ & $40.39 b$ & $40.41 \mathrm{a}$ & $9.37 \mathrm{e}$ & $18.58 \mathrm{c}$ & $13.98 \mathrm{e}$ & $14.87 \mathrm{a}$ & $15.11 \mathrm{~b}$ & $14.99 \mathrm{~b}$ \\
\hline GAZELLE+MAIZE & $37.99 \mathrm{~cd}$ & $38.11 \mathrm{bc}$ & $38.05 \mathrm{a}$ & $16.68 \mathrm{c}$ & $19.58 b$ & $18.13 \mathrm{~b}$ & $16.79 \mathrm{a}$ & $15.86 \mathrm{ab}$ & $16.33 \mathrm{ab}$ \\
\hline TGX1990-5F+MAIZE & $38.43 \mathrm{bcd}$ & $38.54 \mathrm{bc}$ & $38.49 \mathrm{a}$ & $12.77 \mathrm{~d}$ & $15.20 \mathrm{~d}$ & $13.98 \mathrm{e}$ & $16.15 \mathrm{a}$ & $18.82 \mathrm{a}$ & $17.48 \mathrm{a}$ \\
\hline Mean & 39.24 & 39.34 & 39.29 & 15.83 & 17.40 & $16.62 \mathrm{c}$ & 16.19 & 16.75 & 16.47 \\
\hline LSD0.05 & 2.165 & 2.183 & 7.224 & 0.916 & 0.5763 & 2.46 & 2.501 & 2.875 & 1.979 \\
\hline $\mathrm{CV} \%$ & 3.0 & 3.1 & 11.7 & 3.2 & 1.8 & 9.0 & 8.5 & 9.4 & 7.3 \\
\hline \multicolumn{10}{|c|}{ Short rains 2016-2017 } \\
\hline \multirow{2}{*}{ Treatment } & \multicolumn{3}{|c|}{ Protein content } & \multicolumn{3}{|c|}{ Oil content } & \multicolumn{3}{|c|}{ Dray matter } \\
\hline & Embu & Mwea & Mean & Embu & Mwea & Mean & Embu & Mwea & Mean \\
\hline SB19 & $34.53 \mathrm{ab}$ & $31.29 \mathrm{~b}$ & $32.91 \mathrm{~b}$ & $17.47 \mathrm{c}$ & $15.93 b$ & $16.70 \mathrm{~b}$ & $16.01 \mathrm{a}$ & $16.77 \mathrm{~cd}$ & $16.39 \mathrm{ab}$ \\
\hline GAZELLE & $36.15 \mathrm{ab}$ & $31.10 \mathrm{~b}$ & $33.62 b$ & $20.74 a$ & $22.27 \mathrm{a}$ & $21.51 \mathrm{a}$ & $15.15 \mathrm{a}$ & $15.74 \mathrm{de}$ & $15.45 \mathrm{ab}$ \\
\hline TGX1990-5F & $40.14 \mathrm{ab}$ & $34.94 \mathrm{ab}$ & $37.54 \mathrm{ab}$ & $19.03 b$ & $14.98 \mathrm{~b}$ & $17.00 \mathrm{~b}$ & $16.84 \mathrm{a}$ & $17.55 b c$ & $17.19 \mathrm{ab}$ \\
\hline SB19+MAIZE & $38.90 \mathrm{ab}$ & $37.51 \mathrm{a}$ & $38.20 \mathrm{ab}$ & $9.58 \mathrm{e}$ & $15.61 b$ & $12.59 \mathrm{c}$ & $15.53 \mathrm{a}$ & $15.11 \mathrm{e}$ & $15.32 b$ \\
\hline GAZELLE+MAIZE & $33.79 b$ & $30.16 b$ & $31.98 \mathrm{~b}$ & $17.26 \mathrm{c}$ & $18.66 \mathrm{ab}$ & $17.96 b$ & $16.46 \mathrm{a}$ & $18.19 \mathrm{ab}$ & $17.33 \mathrm{a}$ \\
\hline TGX1990-5F+MAIZE & $41.17 \mathrm{a}$ & $40.50 \mathrm{a}$ & $40.84 a$ & $12.77 \mathrm{~d}$ & $15.20 \mathrm{~b}$ & $13.46 \mathrm{c}$ & $16.81 \mathrm{a}$ & $18.82 \mathrm{a}$ & $17.82 \mathrm{a}$ \\
\hline Mean & 37.45 & 34.25 & 35.85 & 16.20 & 16.87 & $16.54 b$ & 16.13 & 17.03 & 16.58 \\
\hline LSD0.05 & 6.253 & 5.895 & 7.224 & 0.7205 & 5.456 & 2.46 & 2.049 & 1.217 & 1.979 \\
\hline $\mathrm{CV} \%$ & 9.2 & 9.5 & 11.7 & 2.4 & 17.8 & 9.0 & 7.0 & 3.9 & 7.3 \\
\hline
\end{tabular}

Note. LSD: Least significant difference; CV: Coefficient of variation.

\section{Discussion}

\subsection{Effects of Intercropping Maize-Soybean on Grain Size}

The higher values of soybean grain size had $6.5 \mathrm{~mm}$ in both sites, where GAZELLE recorded $79.33 \%$ compared to SB19 with $0.67 \%$. Intercropping affected negatively soybean grain size according to the results found in both rainy seasons. This could be due to not only the competition of maize against soybean on nutrient, light and air but also the results of shading of maize on soybean. From this results, William (2012) reported that variety with early maturity are the most to give poor grain quality especially for those variety which their maturity are not unifom. Wet conditions, shading, pressures of some diseases, poor conditions between pysisological maturity and harvest can enhance decreasing of grain quality. SB19 variety known for early maturity produced poor grain quality because of criticals conditions which revealed during the two rainy seasons. Ranking soybean size, GAZELLE had better grain size followed by TGX1990-5F and the last is SB19 (Figure 5). From results, Foundation (2011) reported that GAZELLE is a variety largely cultivated in Kenya and was released in 2009 by KARI Njoro and is high yielding, large grain size, and attractive color. Whan et al. (2014), reported that, grain size is an important trait of both basic plant reseach, since grain formation and development is a fundamental aspect of reproduction, and breeding, as a component of yield and vigour. Thus, each control methods determining grain size tend to either know if grain size did increase or decrease depending of growing conditions. The high value of soybean good grain size ranged from $5.6 \mathrm{~mm}$ to $8 \mathrm{~mm}$. These results have been confirmed by Shahin and Symons (2005) who reported that, depending on the varieties of soybean, grain size can range between $5.56 \mathrm{~mm}$ to $7.54 \mathrm{~mm}$.

\subsection{Effects of Intercropping Maize-Soybean on Protein, Oil Content and Dry Matter}

According to the results found, TGX1990-5F showed significant difference producing high value of protein ranged between (34.94\% to $43.02 \%)$ at both sites and during two rains seasons. The second variety to produce high value of protein is the local variety which is GAZELLE and the last is SB19. Intercropping affected slightly the protein content considering the higher value of protein content for each variety produced in sole crop than in intercropping. GAZELLE variety produced highest value of oil content $(21.08 \%)$ compared to SB19 $(16.46 \%)$ at 
Embu in long rains of 2016. The variety which had the lowest value of oil content was SB19. GAZELLE produced high value of oil content both sites and both rain seasons. Intercropping affected slithly the value fo oil content than sole crop. This could be attributed on the shading of the maize on soybean which could not allow good panetration of light, air, and the competition of nutrient, hence, low protein and oil production. Depending on the results obtained Lithourgidis et al. (2011) found that grain quality traits, protein content and oil content can be affected positively or negatively by growth conditions of crops. In contrary, Erik (2005) reported that, intercropping can have series of quality factors, such as physical grain quality, ratio of nitrogen and sulphur concentrations, protein quality for wheat and fababean. The spacing of soybean between plant was $40 \mathrm{~cm}$ while it was $15 \mathrm{~cm}$ within plant which allowed good oil production in maize-soybean intercropping. That was not the case for Abdel et al. (2016) who reveled that intercropping soybean-sunflower spaced at $20 \mathrm{~cm}$ (soybean) had the highest grain oil yields per ha compared to others spacing. Ayu et al. (2004) recorded maximum protein yield of sorghum under soybean plus sorghum system than sole sorghum. In many cereal-legume intercropping systems there is emanation of favourable exudates from the component legume to the associated cereal and this is suspected to have effects on the quality of the cereal in terms of protein yield. Moreover, Staniak et al. (2014) found that, intercropping of cereals-legumes enhances protein content in the grain cereals, increasing also the yield of crude protein in the biomass of the component crops. Šarūnaite et al. (2010) said that,the increases of crude protein was higher in wheat grain yield when wheat had been grown in intercrop with bean. However, depending on dry matter, TGX1990-5F gave significant diference of dry matter (18.82\% compared to $15.11 \%)$ for SB19 at Mwea for long rains of 2016. Embu site did not give significant difference during long rain of 2016 and short rains of 2016-2017. Futhermore, Musa et al. (2011) reported that intercropping increased chemical composition as dry matter, ash, protein, fiber content and tannin content of cowpea in maize-cowpea intercropping. In addition, Rusdy (2014) showed that intercropping of Panicum maximum and Centrosema pubescens gave dry matter which was significantly different $(p<0.05)$ than their monocrops.

\section{Conclusion}

Intercropping maize-soybean showed that TGX1990-5F variety presented high value of protein content in sole crops and in intercrops followed by GAZELLE compared to SB19. For the oil content, GAZELLE came first showing high value of oil content while TGX1990-5F was second. TGX1990-5F can be recommended to smallscale farmers for intercropping with maize because it can produce high protein content and fight against mal nitrution, and increase maize yields. GAZELLE had higher grain size compared to other varieties.

\section{Acknowledgements}

The authors appreciate Alliance for a Green Revolution in Africa (AGRA) for funding the study through the University of Nairobi. The opinions expressed herein are of the author (s) and do not necessarily reflect the views of AGRA.

\section{References}

Abdel-wahab, S. I., Mahmoud, A., \& Manzlawy, E. (2016). Yield and Quality of Intercropped Sunflower with Soybean Under Different Sunflower Plant Spacings and Slow-Release Nitrogen Fertilizer Rates in Sandy Soil. International Journal of Applied Agricultural Sciences, 2(3), 32-43. https://oi.org/10.11648/ j.ijaas.20160203.11

Ayub, M., Tanveer, A., Nadeem, M. A., \& Shah, S. M. A. (2004). Studies on the Fodder Yield and Quality of Sorghum Grown Alone and in Mixture with Ricebean. Pak. J. Life Soc. Sci., 2, 46-48.

County, E. (2014). Office of the Controller of Budget Embu County Budget Implementation Review Report First Quarter Fy 2013/2014. Nairobi, Kenya.

County, K. (2014). Kirinyaga county transition implementation plan (pp. 1-64). Office of the Governor, Kirinyaga County, Kutus, Kenya.

CSIRO and the Victorian Goverment. (2006). Crude Fat Determination-Soxhlet Method. Food Science (pp. 1-3). Cambella, Australia.

Dragicevic, V., Oljaca, S., Simic, M., Dolijanovic, Z., Kresovic, B., \& Brankov, M. (2017). Content of some antioxidants in intercropped maize and soybean grain. Journal of Agricultural Sciences, 62(1), 31-40. https://doi.org/10.2298/JAS1701031D

Erik, S. (2005). Intercropping of cereals and grain legumes in European organic farming systems (pp. 1-4). Department, Risø National Laboratory, Copenhagen, Danmark.

Eskandari, H., \& Ghanbari, A. (2009). Intercropping of Maize (Zea mays) and Cowpea (Vigna sinensis) as 
Whole-Crop Forage: Effect of Different Planting Pattern on Total Dry Matter Production and Maize Forage Quality. Notulae Botanicae Horti Agrobotanici Cluj-Napoca, 37(2), 152-155.

Foundation, M. G. (2011). About the Bulletin Tropical legume farming in Kenya (pp. 1-12). Agland Investment Services, Inc, Harare, Zimbabwe.

Hauggaard-Nielsen, H., Ambus, P., \& Jensen, E. S. (2001). Reintroducing grain legume-cereal intercropping for increased protein production in European cropping systems. Proceedings of the 4th European Conference on Grain Legumes (pp. 52-53). Taastrup, Denmark.

ILRI-ICRAF. (2007). Genstat Discovery Edition 3 for Everyday Use (pp. 1-116). World Agroforestry Centre, Berkshine, UK.

Kadziuliene, Z., Sarunaite, L., Deveikyte, I., Maiksteniene, S., Arlauskiene, A., Masilionyte, L., ... Zekaite, V. (2009). Qualitative effects of pea and spring cereals intercrop in the organic farming systems. Agronomy Research, 7(SII), 606-611.

Katerine. (2012). Analysis of food and natural products: Determination of total nitrogen in food and crude protein calculation (pp. 1-12). Department of Food Analysis and Nutrition, Prague, Republic of Czech.

Laurent, B., Étienne-Pascal, J., Henrik, H.-N., Christophe, N., Guénaëlle, C.-H., Loïc, P., ... Justes, E. (2014). Eco-Functional Intensification by Cereal-Grain Legume Intercropping in Organic Farming Systems for Increased Yields, Reduced Weeds and Improved Grain Protein Concentration Laurent. Organic Farming, Prototype for Sustainable Agricultures: Prototype for Sustainable Agricultures (pp. 1-489). https://doi.org/ 10.1007/978-94-007-7927-3

Layek, J., Shivakumar, B. G., Rana, D. S., Munda, S., \& Lakshman, A. K. (2015). Effect of nitrogen fertilization on yield, intercropping indices and produce quality of different soybean (Glycine max). India Journal of Agronomy, 60(2), 230-235.

Li, X., Mu, Y., \& Cheng, Y. (2012). Effects of intercropping sugarcane and soybean on growth, rhizosphere soil microbes, nitrogen and phosphorus availability. Acta Physiol Plant, 35(4), 1113-1119. https://doi.org/ $10.1007 / \mathrm{s} 11738-012-1148-\mathrm{y}$

Lithourgidis, A. S., Dordas, C. A., Damalas, C. A., \& Vlachostergios, D. N. (2011). Annual intercrops: An alternative pathway for sustainable agriculture. Australian Journal of Crop Science, 5(4), 396-410.

Masuda, T., \& Goldsmith, P. D. (2009). World Soybean Production: Area Harvested, Yield, and Long-Term Projections. International Food and Agribusiness Management Review, 12(4), 143-162.

Masuda, T., \& Goldsmith, P. D. (2014). World Soybean Production: Area Harvested, Yield, and Long-Term Projections. The international Food and Agribusiness Management Review, 12(4), 143-162.

Mirela, E., \& Roman, G. V. (2013). Research on intercropping effect on crop productivity and yield quality of maize (Zea mays L.)/soybean (Glycine max (L.) Merril), in the organic agriculture system. Scientific Papers. Series A. Agronomy, 50(6), 391-394.

Musa, E. M., Elsheikh, E. A. E., Ahmed, I. A. M., \& Babiker, E. E. (2011). Effect of intercropping, Bradyrhizobium inoculation and N, P fertilizers on yields, physical and chemical quality of cowpea seeds. Front. Agri. China, 5(4), 543-551. https://doi.org/10.1007/s11703-011-1147-6

PFI. (1978). Dry matter content (pp. 1-2). Scandinavian Pulp, Paper and Board Testing Committee, Stockholm, Sweden.

Roy, R., Finck, A., Blair, G., \& Tandon, H. (2006). Nutrient management guidelines for some major field crops. Plant Nutrition for Food Security (pp. 235-248). Rome, Italy.

Rusdy, M. (2014). Dry matter yield and nutritional quality of Panicum maximum-Centrosema pubescens mixtures at different plant proportions and cutting intervals. International Journal of Science , Environment, $3(6), 2231-2241$.

Šarūnaitė, L., Deveikytè, I., \& Kadžiulienè, Ž. (2010). Intercropping spring wheat with grain legume for increased production in an organic crop rotation. Žemdirbyste Agriculture, 97(3), 51-58. Retrieved from http://www.lzi.lt/tomai/97(3)tomas/97_3_tomas_str5.pdf

Shahin, M. A., \& Symons, S. J. (2005). Seed sizing from images of non-singulated grain samples (pp. 49-55). Canadian Grain Commission, Grain Research Laboratory, Winnpeg, Manitoba.

Staniak, M., Księżak, J., \& Bojarszczuk, J. (2014). Mixtures of Legumes with Cereals as a Source of Feed for 
Animals. Organic Agriculture Towards Sustainability (pp. 123-145). INTECH. https://doi.org/10.5772/ 58358

Thoenes, P. (2015). Background paper for the Competitive Commercial Agriculture in Sub-Saharan Africa (CCAA) Study Soybean International Commodity Profile (pp. 1-25). Food and Agriculture Organisation of the United Nations, Thailand, Vietnam.

Weinhold, D., \& Killick, E. (2011). Soybeans, Poverty and Inequality in the Brazilian Amazon (pp. 1-26). London School of Economics, Brazilian, Brazil.

Whan, A. P., Smith, A. B., Cavanagh, C. R., Ral, J. F., Shaw, L. M., \& Howitt, C. A. (2014). GrainScan: A low cost, fast method for grain size and colour measurements. Plant Methods (pp. 1-10). Cambela, Australia. https://doi.org/10.1186/1746-4811-10-23

William, R. (2012). Soybean, variert yields and prroduction practices (pp. 1-12). Louisiana Soybean Information Center, Louisiane, France.

Yucel, C., \& Avci, M. (2009). Effect of different ratios of common vetch and triticale mixtures on forage yields and quality in Cukurova plain in Turkey. Bulgarian Journal of Agricultural Science, 15(4), 323-332.

Zhang, X., Huang, G., \& Zhao, Q. (2014). Differences in maize physiological characteristics, Nitrogen accumulation, And yield under different cropping patterns and nitrogen levels. Chilean Journal of Agricultural Research, 74(3), 326-332. https://doi.org/10.4067/S0718-58392014000300011

\section{Copyrights}

Copyright for this article is retained by the author(s), with first publication rights granted to the journal.

This is an open-access article distributed under the terms and conditions of the Creative Commons Attribution license (http://creativecommons.org/licenses/by/4.0/). 